\title{
Promoting Gender Equality Through Business Education Programme for Entrepreneurship in Bayelsa State, Nigeria
}

\author{
Igbongidi Binaebi Paul
}

Department of Vocational and Technology Education, Niger Delta University, Wilberforce Island, Nigeria

\section{Email address:}

paulbinaebi96@gmail.com

\section{To cite this article:}

Igbongidi Binaebi Paul. Promoting Gender Equality Through Business Education Programme for Entrepreneurship in Bayelsa State, Nigeria. Advances in Sciences and Humanities. Vol. 3, No. 2, 2017, pp. 11-13. doi: 10.11648/j.ash.20170302.11

Received: February 20, 2017; Accepted: April 25, 2017; Published: May 28, 2017

\begin{abstract}
The study examines strategy for promoting gender equality through business education programme for entrepreneurship in Bayelsa State. Two research questions were formulated to guide the study. The descriptive survey research design was adopted. The population for the study comprised of 200 female business education students from the department of vocational and technology education, Niger Delta University, Wilberforce Island, Bayelsa State. The population size was manageable and there was no sampling. The instrument for data collection was a 10 item structured designed by the researcher. Three experts in business education, measurement and evaluation face validated the instrument. The research questions were analyzed using mean and standard deviation. Based on the findings of this study, the following conclusion was drawn; that all the strategies identified are considered effective for promoting gender equality through business education programme for entrepreneurship development. Based on the findings of the study, the following recommendations were made: women should be empowered educationally to take advantage of entrepreneurship programmes; there should be serious campaign to dispel the belief the belief that women do not need education and this should be done culturally, religiously and legally.
\end{abstract}

Keywords: Gender Equality, Business Education Programme, Entrepreneurship, Entrepreneurship Development

\section{Introduction}

Education is seen as a formal process by which society deliberately transmits its accumulated knowledge, skills, customs and values from one generation to another. It involves the process of preparing oneself and others intellectually for mature life through a display of good culture and learning based on information or experience [1].

Across the world today, it source not obvious to say that there is a strong case for greater gender equality in Nigerian System of Education which has of course leads to gender inequality issues. Greater economic opportunities for women can contribute to stronger, better and fairer growth by raising the overall level of human capital and labour productivity and by mobilizing hitherto underutilized labour supply. Helping more people to realize their work and family aspirations through empowerment, more men and women will share the benefits of growth. However, achieving greater gender equality remains a big challenge despite the many gains in women's educational and employment outcomes recorded in recent history[2].
International Planned Parenthood [3] defined gender equality as the measurable equal representation of women and men. This means that gender equality does not imply that women and men are the same, but that they have equal value and should be accorded equal treatment. On the other hand, the United Nations [4] cited gender equality as a human right. It points out that empowering women is also an indispensable tool for advancing development and reducing poverty. In other words, it equal pays for equal work is one of the areas where gender equality is rarely seen. All too often women are paid less than men for doing the same work. Gender equality may be defined as a sex equality, sexual equality or equality of the genders, which can also be referred to the view that men and women should received equal treatment, and should not be discriminated against based on gender, unless there is a sound biological reason for different treatment.

Amaewhule [5] opined that business education encompasses knowledge, attitudes, and skills needed by all citizens in order to effectively manage their personal businesses and economic system. Atakpa [6], remarked that business education is an embodiment of vocational 
knowledge and skills needed for employment and advancement in a broad range of business careers. In other words, business education means education for business or training skills which is required in business offices, clerical occupation and business policy analysis. Osuala [7] further remarked that business education is a programme of instruction which provides students with information and competencies required by all in managing personal business affairs and to render services in the business world. Business Education is a type of training which, while playing its part in the achievement of the general aims of education on any given level, has its primary objective as the preparation of people to enter into a career, to render efficient service and to advance from their present level of employment to higher levels [7]. Basic Business Education affords to every individual an opportunity to develop the skills, abilities and understanding that will enable him to handle competently his personal business affairs; to develop an understanding of the vocational opportunity available in the broad field of business and to assume his citizenship responsibilities through enlightened participation in, as well as an understanding and appreciation of the business system [7]. Furthermore, Basic Business Education is the broad area of knowledge that deals with the economy. It identifies and explains the role of business as an economic institution and provides content and experience that prepare the individual for effective participation as a citizen and consumer.

Entrepreneurship according to Omolayo [8]; Baba [9] is the act of starting a company, arranging business deals and taking risks in order to make profit through the education skills acquired. The entrepreneurship spirit is a pre-requisite to an entrepreneurial society and culture. This spirit is required for the overall economic growth of any nation especially developing ones like Nigeria. This is in line with the view of Nwangwu [10]; Ojeifo [11] that entrepreneurship is the willingness and the ability of an individual or a firm or an organization to identify an environmental change and exploit such an opportunity to produce goods and services for public consumption. Entrepreneurship is a term used broadly to describe an innovative modern industrial business leader [12]. He/she has been described as the person who perceives business opportunities and uses the scarce resources available to take advantage of them. It is entrepreneur alone who bears the noninsurable risks in his enterprise and it is he/she who directs the human and materials resources in business legal goals.

The concept entrepreneurial development has been defined in various ways. However referring to the productive transformation of an entrepreneur, a single thread runs through all of them: the ability to identify business opportunities, the ability to be able to harness the necessary resources to use opportunities identified, the ability and willingness to initiate and sustain appropriate actions towards the actualization of business objectives. Osemeke (2012) in cited Nwankwo, Nweke \& Ademu [13] define entrepreneurship development as the process of enhancing entrepreneurial skills and knowledge through structured training and institution-building programmes. Entrepreneurship Development aims to enlarge the base of entrepreneurs in order to hasten the pace at which new ventures are created. This accelerates employment generations and economic development. Entrepreneurial development focuses on the individual who wishes to start or expand a business.

\subsection{Purpose of the Study}

The broad purpose of the study is to determine strategies for promoting gender equality through entrepreneurship education for entrepreneurship development in Bayelsa State. Specifically, the study seeks to:

1. Identify the effective strategies for promoting gender equality through business education in Bayelsa State.

2. Identify the effective strategies for promoting women education for entrepreneurship development in Bayelsa State.

\subsection{Research Questions}

The following research questions are formulated to guide the study

1. What are the appropriate strategies for promoting gender equality through business education for entrepreneurship development in Bayelsa State?

2. What are the appropriate strategies for promoting women education for entrepreneurship development in Bayelsa State?

\section{Methodology}

The study adopted a descriptive survey design. The population for the study comprised of 200 female business education students from the department of vocational and technology education, Niger Delta University, Wilberforce Island, Bayelsa State. The population size was manageable and there was no sampling. The instrument for data collection was a 10 item structured designed by the researcher. Three experts in business education, measurement and evaluation face validated the instrument. The research questions were analyzed using mean and standard deviation.

\subsection{Results}

Research Question one: What are the appropriate strategies for promoting gender equality through business education for entrepreneurship development in Bayelsa State?

Table 1. Mean and standard deviation of respondents on the strategies for promoting gender equality through business education.

\begin{tabular}{lllll}
\hline S/N & Strategies & Mean & $\begin{array}{l}\text { Standard } \\
\text { Deviation }\end{array}$ & Remarks \\
\hline 1. & Training and development & 3.83 & 0.39 & Agreed \\
2. & Agricultural Empowerment & 3.42 & 0.79 & Agreed \\
3. & Education Empowerment & 3.80 & 0.54 & Agreed \\
4. & Economic Empowerment & 3.33 & 0.70 & Agreed \\
5. & Legal backing & 3.11 & 0.42 & Agreed \\
\hline
\end{tabular}

Research Question Two: What are the appropriate strategies for promoting women education for entrepreneurship development in Bayelsa State? 


\subsection{Discussion of Results}

Findings of the study as indicated in table 1 revealed that the ten items had means ranging from 2.50 to 3.83 indicating that all the respondents were positive in their opinions that those items are strategies for promoting gender equality through business education for entrepreneurship development in Bayelsa State. This finding is line with Correll [14] who asserted that improving the status of women enhances their decision making capacity at all levels in all spheres of life and this can only be achieved by employing such strategies as educational, political, agricultural, economic empowerment and through laws and policy.

The result in Table 2 showed that all the items are strategies for promoting women education for entrepreneurship development. This finding is in line with Enechojo \& Orhungur [15] that establishing functional literacy programmes for women, campaign to dispel belief that women do not need education are strategies for promoting women education for entrepreneurship development.

Table 2. Mean and standard deviation of respondents on the strategies for promoting women education for entrepreneurship development.

\begin{tabular}{|c|c|c|c|c|}
\hline $\mathbf{S} / \mathbf{N}$ & Strategies & Mean & Standard Deviation & Remarks \\
\hline 1. & Seminars/workshops should be organized to train women in various income generating skills & 3.75 & 0.45 & Agreed \\
\hline 2. & Establishing integrated functional literacy programme & 3.42 & 0.79 & Agreed \\
\hline 3. & Enlightenment campaign on the importance of women education & 3.50 & 0.90 & Agreed \\
\hline 5. & Campaign to dispel belief that women do not need education & 3.92 & 1.24 & Agreed \\
\hline
\end{tabular}

\section{Conclusions}

Based on the findings of this study, the following conclusion was drawn; that all the strategies identified are considered effective for promoting gender equality through business education programme for entrepreneurship development.

\section{Recommendations}

Based on the findings of the study, the following recommendations were made;

1. Women should be empowered educationally to take advantage of entrepreneurship programmes

2. There should be serious campaign to dispel the belief the belief that women do not need education and this should be done culturally, religiously and legally.

\section{Acknowledgement}

The authors wish to thank the students in the Department of Vocational and Technology Education who served as respondents and also to the reviewer of this work for his corrections and suggestions.

\section{References}

[1] Ocho, L. O. (2005). Basic Resources needs for successful business Management. In Nwangu I. O. Education and Life Issues and Concerns. Enegu: Institute for Development Studies.

[2] Kelly, B. O. (2013). Gender equality and women empowerment in Nigeria: The desirability and inevitability of a pragmatic approach. Developing Country Studies, 3(4), 7 Retrieved from: http://www.iiste.org.

[3] IPPF (2013). UK Registered Charity No. 229476. 4 Newhams Row London. International Planned Parenthood Federation. Retrieved from: http://www.ippf.org.

[4] United Nations (2011), "Declaration on human rights," New
York: United Nations.

[5] Amaewhule, W. (2000) An introduction to vocational education and administration. Owerri: Springfield publishers.

[6] Atakpa, R. A. (2011). Entrepreneurship education: A sine quanon in business education in Nigeria. Business Education Journal, 1(11), 1-6.

[7] Osuala, (2003), Principles and Practice of Business Education, Pacific Publishers: Anambra State.

[8] Omolayo, B. (2006). Entrepreneurship in theory and practice in Onsotosho, Aluko, Wale Awe \& Adaramola (eds). Introduction to Entrepreneurship development in Nigeria. Ado-Ekiti: UMAD Press.

[9] Baba, G. K. (2013). The challenges of Entrepreneurship Development in Nigeria and way forward, Journal of Business and Organizational Development, Vol. 5, (1), 54-64.

[10] Nwagwu, I. O. (2007). Higher Education for Self-Reliance: an Imperative for the Nigerian Economy, NEAP Publication.

[11] Ojeifo, S. A. (2013). Entrepreneurship Education in Nigeria. A Panacea for Youth Unemployment. Journal of Education and Practice, Vol. 4 (6), 61 - 67.

[12] Akpomi, M. E. (2008), Developing Entrepreneurship Education Programme (EEP) for Higher Education Institutions (HEIs) in Nigeria. Post-doctoral research project carried out at the University of Reading, Reading UK.

[13] Nwankwo B. C., Nweke P. O. \& Ademu Yunusa (2014) Gender equality in education and youth employment through entrepreneurship development. International Journal of Youth Empowerment and Entrepreneurship Development Vol. 1(1), 9-23, December 2014 | Maiden Edition (C) 2014 IJYEEDJournal. Available online at http://www.ijyeedjournal.com.

[14] Correll, S. J., (2001). Gender and the Career Choice Process: The role of biased self Assessments. American Journal of Sociology (106), 1691-1730.

[15] Enechojo, G. E. \& Orhungur, M. M. (2012). Gender issues In entrepreneurial development in Benue State (Nigeria) and counseling implications. BJSEP: Bulgarian Journal of Science and Education Policy, 6(2) 201. 